\title{
Original article (Orijinal araştırma) \\ Some biological parameters of Orius niger (Wolff, 1811) (Hemiptera: Anthocoridae) under outdoor conditions in Turkey
}

\author{
Orius niger (Wolff, 1811) (Hemiptera: Anthocoridae)'in dış koşullarda bazı biyolojik özellikleri
}

\author{
Serkan PEHLIVAN ${ }^{1}$
}

\author{
Ekrem ATAKAN ${ }^{1 *}$
}

\section{Summary}

Overwinter biology of Orius niger (Wolff, 1811) (Hemiptera: Anthocoridae) was studied during 2014 and 2015, in Adana Province, Turkey. Outdoor experiments were performed at the Department of Plant Protection, Faculty of Agriculture, University of Çukurova on seven different dates between October and April. The predatory bug, O. niger, overwinters in Adana Province as adults. Some biological parameters of the O. niger were investigated under outdoor conditions at monthly intervals from autumn to spring with cotton seedlings placed in vials with distilled water. Sterilized eggs of the Mediterranean flour moth, Ephestia kuehniella Zeller, 1879 (Lepidoptera: Pyralidae), were provided to Orius as food. All eggs of $O$. niger hatched even at the low temperatures in winter. Most of the experimental females laid eggs. Total mean numbers of eggs laid by the females was the highest in April

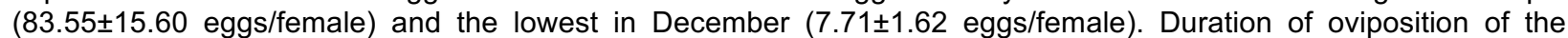
experimental females was nearly 30 days in October, November and April, but less than 30 days in other winter months. The proportion of non-reproductive females in December-February ranged from $25 \%$ to $40 \%$. Longevity of females was nearly a month in winter and they did not survive until spring. While sex ratios (male/female) ranged from 1:2.5 to 1:3 in October-January, the ratio was 1:1 in April. Duration of nymph development was the highest (45 days) in January and the shortest (nearly 18 days) in April. Furthermore, most of the first instars of nymphs died in a short time due to cold winter days in December-February, and nearly $28 \%$ total nymphs matured to adults. The experimental results support that $O$. niger can severely decrease the population sizes of pest species in late spring (after April) in countries of the southern zone.

Keywords: Adana, Anthocoridae, biology, Orius niger, Turkey

\section{Özet}

Orius niger (Wolff, 1811) (Hemiptera: Anthocoridae)'in kışlama biyolojisi Adana'da 2014 ve 2015 yıllarında araştırılmıştır. Dış koşullardaki denemeler Ekim-Nisan periyodunda Çukurova Üniversitesi, Ziraat Fakültesi, Bitki Koruma Bölümü'nde 7 farklı tarihte yürütülmüştür. Avcı böcek O. niger Adana'da ergin olarak kışı geçirmektedir. Orius niger'in bazı biyolojik özellikleri Sonbahar-İlkbahar periyodunda dış koşullarda incelenmiştir. O. niger' e besin olarak sterilize edilmiş Akdeniz un güvesi, Ephestia kuehniella Zeller, 1879 (Lepidoptera: Pyralidae) yumurtaları verilmiştir. Kışın çok düşük sıcaklıklarda bile $O$. niger'in yumurtaları açılmıştır. Tüm denemelerdeki dişilerin birçoğu

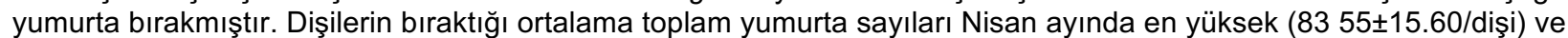
Aralık ayında ise en düşük $(7.71 \pm 1.62 /$ dişi) olmuştur. Ekim, Kasım ve Nisan aylarında dişilerin ovipozisyon süresi 30 gün civarında olurken, diğer kış aylarında bu süre 30 günden az olmuştur. Yumurta bırakmayan dişilerin oranı ise Aralık-Şubat döneminde \%25-\%40 arasındadır. Dişilerin ömür süreleri kışın yaklaşık olarak bir aydır ve dişiler ilkbahar dönemine ulaşamamıştır. Ekim-Ocak ayları arasında cinsiyet oranları (dişi/erkek) 1:2.5'ten 1:3'e kadar değişirken, bu oran Nisan ayında 1:1 olmuştur. Nimf gelişme süreleri Ocak ayında en uzun (45 gün) olurken Nisan ayında en kısa (18 gün) olarak belirlenmiştir. Aralık-Şubat dönemindeki soğuk kış günlerinde birinci dönem nimflerin birçoğu kısa sürede ölürken, yaklaşık \%28'i ergin döneme ulaşmıştır. Bu denemenin sonuçları O. niger'in güney bölgelerde nisan ayından sonra zararlı türlerin popülasyonlarını azaltabileceğini desteklemektedir.

Anahtar sözcükler: Adana, Anthocoridae, biyoloji, Orius niger, Türkiye

\footnotetext{
${ }^{1}$ University of Çukurova, Faculty of Agriculture, Department of Plant Protection, 01330, Sarıçam, Adana, Turkey

* Corresponding author (Sorumlu yazar) e-mail: eatakan@mail.cu.edu.tr

Received (Alınış): 31.01.2017 Accepted (Kabul ediliş): 22.06.2017

Published Online (Çevrimiçi Yayın Tarihi): 03.07.2017
} 


\section{Introduction}

The Order Hemiptera is well known for containing important predators of agricultural pests including acari (Acarina) and thrips (Thripidae), as well as other soft bodies pest species (Whitcomb \& Bell, 1964). Commonly they are used in integrated pest management programs (IPM) with their high consumption and searching capabilities on their host, their easy mass rearing and quick adaptability to laboratory conditions (Ramakers \& van den Meiracker, 1991; Van de Veire \& Degheele, 1992; Jacopson, 1993).

The western flower thrips, Frankliniella occidentalis Pergande, 1895 (Thysanoptera: Thripidae), is regarded as a very destructive pest of agricultural crops worldwide (Kirk \& Terry, 2003). This species was recorded for the first time in Turkey in 1993 (Tunç \& Göçmen, 1994). In general, insecticide treatments are not efficient on thrips, because of their cryptic behavior, such as eggs being in plant tissues, and prepupa and pupa mostly in soil. Moreover, resistant population can appear because of high number of chemicals (insecticide) used worldwide (Immaraju et al., 1992; Brødsgaard, 1994; Dağlı \& Tunç, 2007). Therefore, there is special attention given to biological control agents belonging to the family Anthocoridae (Hemiptera) to use against pest thrips in agricultural habitats all over the world. Orius species are important as biological control agents in controlling of pest thrips species on vegetables grown in tunnels or greenhouses (Schreuder \& Ramakers, 1989; Trottin-Caudal et al., 1991; Tavella et al., 1991; Villevieille \& Millot, 1991; Van de Veire \& Degheele, 1992; Jacopson, 1993). They also feed upon whiteflies (Hemiptera: Aleyrodidae), aphids (Aphididae) and spider mites (Acarina: Tetranychidae) (Riudavets, 1995). These predator species were previously found on different pest species on cotton in the Çukurova Region, Turkey (Ghavami \& Özgür, 1992) and they have an important role in suppressing thrips species in cotton fields in Turkey (Atakan, 2006; Atakan \& Gencer, 2008) as well as thrips species on vegetables (Atakan, 2007a) and fruit trees (Atakan, 2007b). Also, Orius niger (Wolff, 1811) has been commonly found in Turkey (Önder, 1982) and it is widely spread over the Mediterranean basin and is present under natural conditions throughout the year in the Çukurova Region (Atakan \& Tunç, 2010). Orius niger and Orius minutus (L.) have effectively controlled the two-spotted red spider mite and onion thrips in potato fields in the Ardabil region of Iran (Fathi, 2009).

There are several factors that can influence efficiency of Orius species in IPM programs. The first factor is their behavior in winter (Ramakers \& van den Meiracker, 1991; Gillespie \& Quiring, 1993). Temperature and day length are important factors which affect biological control of thrips by Orius species, while $F$. occidentalis is well known as a very harmful greenhouse pest thrips, which does not enter reproductive diapause (Kirk \& Terry, 2003). It has numerous generations under warm greenhouse conditions, while local or imported strains of some Orius species exhibit a diapause, which negatively effects their predation on pest thrips. However, the Antalya strain of O. niger (Bahşi \& Tunç, 2008) and southern strain of Orius laevigatus (Fieber, 1860) from Sicily (Tommasini \& van Lanteren, 2003) do not enter reproductive diapause under the short-day-length conditions in the laboratory. However, outdoor conditions are quite variable compared to laboratory conditions. Changeable outdoor conditions (mainly meteorological conditions) would affect winter biology of the predatory bug, i.e., diapause, and would have an impact on its potential predatory capacity in controlling pest insects including thrips in crop and wild plants in open fields and in protected areas.

The purpose of this study was to provide data on overwintering status of $O$. niger under outdoor conditions in Adana, Turkey, with emphasis on its potential usage in IPM programs including thrips pest management in agricultural crops. We investigated how different dates, i.e., months, influence biology of $O$. niger. In addition, we also evaluated whether different day lengths and temperatures at different times from winter to spring affected reproductive behavior of the predator bug. Additionally, investigation of overwintering biology of this predatory bug may help to predict predatory activity of $O$. niger on insect prey in agricultural areas in the following season. 


\section{Material and Methods}

\section{Host plant source}

Cotton (Gossypium hirsutum L.) (Malvaceae) cv. SG125 was used in this study. Cotton plants grown in pods in the chambers at $25^{\circ} \mathrm{C}$ and $60 \% \mathrm{RH}$. The cotton seedlings were used for the experiments when they were in two-true leaf stage.

\section{Insect material}

Colonies of Ephestia kuehniella Zeller, 1879 was supplied by the Biological Control Research Institute of Adana and was reared in the laboratory for two years.

Orius niger was obtained from the cotton flowers in Adana, Turkey. Orius individuals were reared in the climatic chamber at $25^{\circ} \mathrm{C}, 60 \% \mathrm{RH}$ and $16 \mathrm{~L}: 8 \mathrm{D}$ h photoperiod. Plastic cups ( $0.5 \mathrm{I}$ capacity) with two ventilation windows covered with muslin were used as rearing units. Fresh bean pods were used as oviposition substrate. Ephestia kuehniella eggs were sterilized for $2 \mathrm{~h}$ under UV light, then glued on blue cards for $O$. niger feeding. Given of the cannibalism of $O$. niger, adults were put in other rearing cages. The rearing units were used to determine egg hatching and nymphal development. Upper side of the 500-ml plastic containers were cut and covered with fine muslin. Thirty-ml capacity glass vial was fixed onto bottom side and cotton seedling with two cotyledon leaves were immersed in water in the glass vial $(7.6 \times 2.5 \mathrm{~cm})$.

\section{Experimental design}

Experiments were conducted on seven different dates between October and April. The plastic containers with cotton seedlings and insects were randomly placed outdoors. The plastic containers including insects were placed on a platform $3 \mathrm{~m}$ above ground outside a south-facing laboratory window. The platform, $90 \mathrm{~cm}$ in diameter, was made from concrete.

\section{Meteorological conditions at the experiment site}

The experiments were conducted in the Department of Plant Protection, Faculty of Agriculture, University of Çukurova. Experiments were performed under outdoor conditions. The mean, maximum and minimum temperatures and relative humidity were obtained from the Meteorological Station of Department of Agricultural Buildings and Irrigation (about $5 \mathrm{~km}$ from the experimental site).

\section{Duration of egg development}

Five pairs (10 replicates) of females (in oviposition period) and males of 0 . niger from the laboratory culture were caged in a plastic container and were kept for $24 \mathrm{~h}$ in the climatic chamber with the conditions $25^{\circ} \mathrm{C}, 60 \% \mathrm{RH}$ and $16 \mathrm{~L}: 8 \mathrm{D} \mathrm{h}$ photoperiod. The bugs were released in the cage which contained sterilized eggs of E. kuehniella and Typha pollen (supplied by the Biological Control Research Institute of Adana, Turkey) on cotyledons of cotton plants. After $24 \mathrm{~h}, \mathrm{O}$. niger eggs laid into the cotyledons were counted in laboratory and 10 eggs were left in each plant cage. The plastic containers were placed outdoors at each experimental date.

Hatching of eggs inserted into the tissues of caged cotton seedlings was assessed daily under a stereo microscope in the laboratory and recorded. The experiments started on 14 October, 5 November, 4 December, 1 January, 3 February, 3 March and 20 April.

\section{Nymphal survival rate}

Newly hatched five nymphs from the egg development experiments under the outdoor conditions, were kept in a plastic container and provided with sterilized eggs of E. kuehniella and also Typha pollens. Experiment was replicated four times (20 nymphs in total). Nymph development was observed twice a week and emerged adults were sexed. The number of emerged adults in relation to the initial number of eggs was calculated from data of development duration experiments.

The experiments started on 20 October, 17 November, 12 December, 13 January, 9 February, 17 March and 25 April. 


\section{Preoviposition, oviposition, postoviposition and fecundity of females}

We modified the method of Chyzik et al. (1995) for these studies. Ten pairs of one-day old bugs obtained from the laboratory stock culture were used. One unmated female and a male were taken from the $O$. niger rearing chambers and were kept in a plastic container with cotton seedlings immersed in water in a vial. Ephestia sterilized eggs and pollens were added. The plastic containers were placed on the same platform. Cotton seedlings and prey were changed every 2 or 3 days. The numbers of eggs laid into plant tissues by the females were counted under a stereo microscope (40x magnification).

The experiments started on 13 October, 3 November, 3 December, 5 January, 2 February, 9 March and 20 April.

\section{Longevity}

Male and female longevity were determined from the individuals used in fecundity test.

\section{Data analysis}

Biological data on eggs hatching, preoviposition, oviposition, postoviposition, eggs numbers and nymph development and adult life span according to experimental days were compared by using Tukey's honestly significant difference (HSD) test at $P<0.05$ significant level. SPSS statistical package program was used (SPSS, 2006).

\section{Results}

\section{Duration of egg development}

Number of laid eggs ranged between 43 (14 October) and 303 (3 February) eggs/female across the different experiment dates. The duration of first hatching of eggs was similar in experiments in October and November and hatching period lasted $5.70 \pm 0.89$ and $6.75 \pm 0.64$ days after first hatching (Table 1). The first hatching occurred 10 days later in December and January experiments. After January, duration of the first hatching was significantly shorter than those in December and January $\left(F_{(6,43)}=15.442, P<0.0001\right)$ than other sampling months. Hatching rate was determined as $62.80 \%$ in October and $76.78 \%$ in November when the eggs hatched within 10 days (Table 1). This rate was $94.01 \%$ in experiment of January. Ratio of hatching of eggs within first 5 days in April experiment was $34.31 \%$.

\section{Nymph development period and mortality rate}

Total nymphal period was the shortest $(17.50 \pm 0.18$ days $)$ in April $\left(F_{(6,40)}=43.447, P<0.0001\right)$ and this was followed by nymphs of September experiment (20.07 \pm 1.10 days) (Table 2). Duration of nymph development coming from the experiments of November, December and January were 32.51 \pm 0.50 , $37.71 \pm 1.74$ and $45.00 \pm 0.40$ days, respectively. Duration of nymph development was the highest at $45.00 \pm 0.40$ days in January and the shortest at $17.50 \pm 0.18$ days in April.

Mean temperature ranged from 19 to $23^{\circ} \mathrm{C}$ and relative humidity was nearly $70 \%$ in April (Figure 1). Nymph development time was closely related to temperature and humidity. Mean temperature varied between 5 and $13^{\circ} \mathrm{C}$ in December-February and dropped to $3^{\circ} \mathrm{C}$ in the first week of January. Out of 54 nymphs, a total 189 nymphs matured to adults. Mortality rate of nymphs in November-February was over $70 \%$. Sixty percent of nymphs in the October experiment and $44 \%$ in the March experiment matured to adults. Numbers of the emerged females were at least two-fold of numbers of the males in OctoberJanuary (Table 2). After the February experiment, the sex ratio was nearly equal. 
Table 1. Duration of Orius niger egg development under the outdoor conditions

\begin{tabular}{|c|c|c|c|c|c|}
\hline \multirow{2}{*}{ Experiment date } & \multirow{2}{*}{ No of total eggs } & \multirow{2}{*}{$\begin{array}{l}{ }^{a} \text { Mean time } \pm \text { SEM of first } \\
\text { hatching of eggs (day) }\end{array}$} & \multicolumn{3}{|c|}{$\begin{array}{l}\text { Hatching rates of eggs (\%) according to day } \\
\text { intervals }\end{array}$} \\
\hline & & & $0-5$ days & 6-10 days & $>10$ days \\
\hline 14 October & 43 & $\begin{array}{l}5.70 \pm 0.89 \mathrm{bc} \\
\quad(4-10)^{\mathrm{b}}\end{array}$ & 4.65 & 32.55 & 62.80 \\
\hline 5 November & 100 & $\begin{array}{c}6.75 \pm 0.64 \mathrm{ab} \\
(5-10)\end{array}$ & 4.05 & 41.41 & 54.54 \\
\hline 4 December & 81 & $\begin{array}{l}9.66 \pm 0.74 \text { a } \\
(8-15)\end{array}$ & 0.00 & 23.22 & 76.78 \\
\hline 1 January & 218 & $\begin{array}{l}9.87 \pm 0.79 \text { a } \\
\quad(8-14)\end{array}$ & 0.00 & 5.96 & 94.04 \\
\hline 3 February & 303 & $\begin{array}{l}3.75 \pm 0.36 \mathrm{bc} \\
(2-5)\end{array}$ & 9.25 & 64.64 & 26.07 \\
\hline 3 March & 150 & $\begin{array}{l}4.20 \pm 0.80 \mathrm{bc} \\
(2-7)\end{array}$ & 10.00 & 58.00 & 32.00 \\
\hline 20 April & 102 & $\begin{array}{c}2.60 \pm 0.76 \mathrm{c} \\
(1-5)\end{array}$ & 34.31 & 65.68 & 0.00 \\
\hline
\end{tabular}

${ }^{a}$ means with same letter in the same column are not statistically significant according to Tukey's HSD test (P < 0.05$)$; ${ }^{b}$ parenthesis indicates minimum and maximum values.

Table 2. Total development time of Orius niger nymphs under outdoor conditions

\begin{tabular}{|c|c|c|c|c|c|c|}
\hline Experiment date & $\mathrm{n}$ & $\begin{array}{l}\text { No of nymphs } \\
\text { became adults }\end{array}$ & $\begin{array}{l}\text { No of death } \\
\text { nymphs }\end{array}$ & $\begin{array}{c}\text { Mortality of nymphs } \\
(\%)\end{array}$ & $\begin{array}{l}{ }^{\mathrm{a}} \text { Mean duration } \pm \text { SEM } \\
\text { of total nymph (day) }\end{array}$ & $\begin{array}{c}\text { Sex ratio } \\
\text { (Male/female) }\end{array}$ \\
\hline 15 October & 25 & 13 & 12 & 48.00 & $\begin{array}{l}20.07 \pm 1.13 \mathrm{c} \\
(16-29)^{\mathrm{b}}\end{array}$ & $1: 3$ \\
\hline 17 November & 25 & 7 & 18 & 72.00 & $\begin{array}{l}32.51 \pm 0.5 b \\
(32-33)\end{array}$ & $1: 2.5$ \\
\hline 12 December & 24 & 2 & 22 & 91.67 & $\begin{array}{l}37.71 \pm 1.74 a \\
\quad(31-43)\end{array}$ & - \\
\hline 13 January & 30 & 4 & 26 & 86.67 & $\begin{array}{l}45.00 \pm 0.40 a \\
\quad(44-46)\end{array}$ & $1: 3$ \\
\hline 9 February & 30 & 5 & 25 & 83.33 & $39.00 \pm 1.34 a(36-42)$ & $1: 1.5$ \\
\hline 17 March & 25 & 9 & 14 & 56.00 & $\begin{array}{c}31.62 \pm 2.23 b \\
(23-42)\end{array}$ & $1: 1.25$ \\
\hline 25 April & 30 & 14 & 16 & 53.00 & $\begin{array}{c}17.5 \pm 0.18 \mathrm{c} \\
(17-18)\end{array}$ & $1: 1$ \\
\hline
\end{tabular}

a means with same letter in the same column are not statistically significant according to Tukey's HSD test $(P<0.05) ;{ }^{\text {b }}$ parenthesis indicates minimum and maximum values. 


\section{Preoviposition, oviposition, postoviposition and productivity of females}

Preoviposition period in the October experiment was significantly shorter at 4.33 days than those in the other experiments $\left(F_{(6,42)}=11.660, P<0.0001\right)$ but increased to $9.33 \pm 0.76$ and $11.71 \pm 1.65$ days in the November and December experiments, respectively (Table 3). Preoviposition period for the March and April experiments lasted $7.42 \pm 1.63$ and $8.72 \pm 1.46$ days, respectively. Oviposition time in the October, November, March and April experiments were significantly greater than those in the winter experiments $\left(F_{(6,42)}=6.712, P<0.0001\right)$ and nearly lasted 30 days. Oviposition was significantly less in the winter experiments $(P<0.0001)$. For example, female oviposited was 11.85 and 18.50 days in the December and January experiments, respectively. Females laid significantly more eggs in October and in April $\left(F_{(6,42)}=4.669, P<0.0001\right)$. Postoviposition in the autumn experiments was significantly longer than in the other experiments, and lasted nearly 10 days.

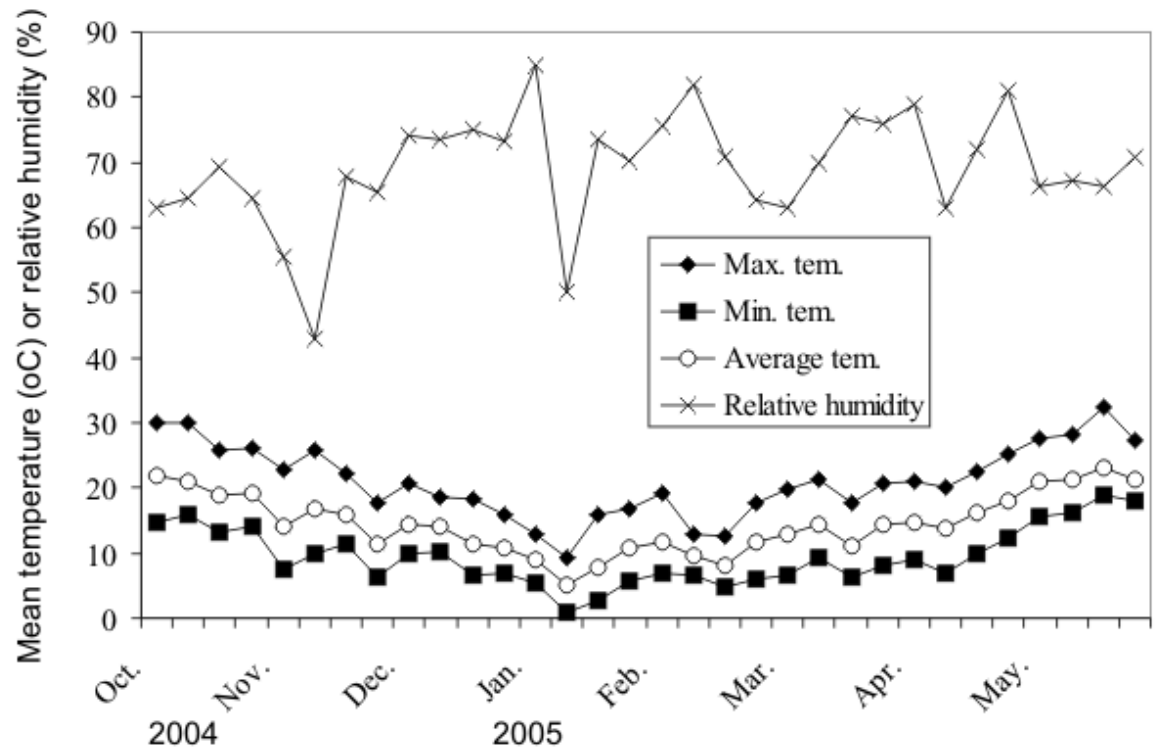

Figure 1. Average, maximum and minimum temperature and relative humidity, October 2014-May 2015 at Balcalı, Adana, Turkey.

Table 3. Duration of preoviposition, oviposition and postoviposition of Orius niger females and fecundity under outdoor conditions

\begin{tabular}{|c|c|c|c|c|c|}
\hline Experiment date & $n$ & $\begin{array}{l}{ }^{\text {a }} \text { Preoviposition time } \\
\text { (day) }\end{array}$ & $\begin{array}{l}\text { Oviposition time } \\
\text { (day) }\end{array}$ & Postoviposition time (day) & $\begin{array}{c}\text { Eggs laid } \\
\text { (egg/female) }\end{array}$ \\
\hline 13 October & 9 & $\begin{array}{c}4.33 \pm 0.33 c \\
(4-6)^{b}\end{array}$ & $\begin{array}{l}30.33 \pm 4.45 a \\
\quad(14-48)\end{array}$ & $\begin{array}{l}7.44 \pm 1.66 \mathrm{a} \\
\quad(2-18)\end{array}$ & $\begin{array}{c}58.22 \pm 9.14 b \\
(34-109)\end{array}$ \\
\hline 3 November & 9 & $\begin{array}{c}9.33 \pm 0.76 \mathrm{~b} \\
\quad(5-12)\end{array}$ & $\begin{array}{c}28.60 \pm 8.31 a \\
(4-87)\end{array}$ & $\begin{array}{c}10.22 \pm 4.62 \mathrm{a} \\
(2-37)\end{array}$ & $\begin{array}{c}27.55 \pm 9.11 \mathrm{c} \\
(8-95)\end{array}$ \\
\hline 3 December & 9 & $\begin{array}{c}11.71 \pm 1.65 \mathrm{~b} \\
(7-19)\end{array}$ & $\begin{array}{c}11.85 \pm 3.26 \mathrm{~b} \\
(2-29)\end{array}$ & $\begin{array}{c}5.28 \pm 1.30 \mathrm{~b} \\
(2-12)\end{array}$ & $\begin{array}{l}7.71 \pm 1.62 \mathrm{e} \\
\quad(2-12)\end{array}$ \\
\hline 5 January & 10 & $\begin{array}{c}19.25 \pm 3.83 a \\
(8-21)\end{array}$ & $\begin{array}{c}18.50 \pm 8.42 b \\
(3-35)\end{array}$ & $\begin{array}{l}4.25 \pm 1.03 \mathrm{~b} \\
\quad(2-14)\end{array}$ & $\begin{array}{c}18.50 \pm 7.18 d \\
(4-36)\end{array}$ \\
\hline 2 February & 10 & $\begin{array}{c}13.35 \pm 1.21 \mathrm{ab} \\
(5-16)\end{array}$ & $\begin{array}{c}18.50 \pm 3.61 b \\
(5-32)\end{array}$ & $\begin{array}{c}4.16 \pm 0.74 b \\
(3-6)\end{array}$ & $\begin{array}{c}15.16 \pm 2.41 \text { de } \\
(9-26)\end{array}$ \\
\hline 9 March & 9 & $\begin{array}{c}7.42 \pm 1.63 \mathrm{~b} \\
(2-14)\end{array}$ & $\begin{array}{c}25.75 \pm 7.56 a \\
(3-59)\end{array}$ & $\begin{array}{l}4.57 \pm 0.81 \mathrm{~b} \\
\quad(2-7)\end{array}$ & $\begin{array}{c}48.83 \pm 12.63 b \\
(22-115)\end{array}$ \\
\hline 20 April & 7 & $\begin{array}{c}8.42 \pm 1.46 \mathrm{~b} \\
(4-16)\end{array}$ & $\begin{array}{c}28.71 \pm 4.08 a \\
(13-41)\end{array}$ & $\begin{array}{c}3.42 \pm 0.48 \mathrm{~b} \\
(2-5)\end{array}$ & $\begin{array}{c}83.85 \pm 15.60 \mathrm{a} \\
(35-135)\end{array}$ \\
\hline
\end{tabular}

${ }^{a}$ means with same letter in the same column are not statistically significant according to Tukey's HSD test $(P<0.05) ;{ }^{b}$ parenthesis indicates minimum and maximum values. 
Eggs numbers were significantly greater, with mean of $83.65 \pm 15.60$ eggs/female, in the April experiment $\left(F_{(6,42)}=6.557, P<0.0001\right)$. Mean numbers of eggs laid by females for first 10 days in October and April were similar at 23.3 and 21.30 eggs/female, respectively, but these numbers were significant different from those in the other experiments $\left(F_{(6,63)}=9.247, P<0.0001\right)$. Mean numbers of eggs laid by female for first 10 days in the January experiment was 3.10 eggs/female (Table 4). In April, females laid significantly more eggs $(50.20$ eggs $)$ in $11-30$ day period $\left(F_{(6,63)}=13.792, P<0.0001\right)$. Mean numbers of eggs laid for more than 31 days were similar, excluding the December experiment, and less even in the October and April experiments. All females laid eggs in first 10 days and 11-30 days in the October and April experiments, respectively. Forty percent of females tested in January and February laid eggs in first 10 days. Only one female oviposited for 31 days (Table 4). Thirty percent of females in December, $40 \%$ in January and $25 \%$ February did not lay egg. In the other experiments, all females oviposited.

Table 4. Fecundity of Orius niger females under outdoor conditions

\begin{tabular}{|c|c|c|c|c|c|c|}
\hline \multirow[t]{2}{*}{ Experiment date } & \multicolumn{3}{|c|}{$\begin{array}{l}{ }^{a} \text { Mean numbers of eggs laid according to day intervals } \\
\text { (egg/female) }\end{array}$} & \multicolumn{3}{|c|}{$\begin{array}{c}\text { Rate of ovipositing females (\%) according } \\
\text { to day intervals }\end{array}$} \\
\hline & $0-10$ & $11-30$ & $>31$ & $0-10$ & $11-30$ & $>31$ \\
\hline 13 October & $23.30 \pm 5.18 \mathrm{a}$ & $25.0 \pm 4.56 b$ & $6.00 \pm 2.96 \mathrm{a}$ & 100 & 100 & 30 \\
\hline 3 November & $11.40 \pm 2.23 b$ & $6.00 \pm 2.04 \mathrm{c}$ & $8.60 \pm 5.98 \mathrm{a}$ & 90 & 60 & 40 \\
\hline 3 December & $3.90 \pm 1.43 c$ & $1.50 \pm 0.96 c$ & - & 70 & 30 & 0 \\
\hline 5 January & $3.10 \pm 1.36 c$ & $3.20 \pm 2.15 c$ & $1.10 \pm 1.10 b$ & 40 & 20 & 10 \\
\hline 2 February & $4.80 \pm 1.94 c$ & $3.80 \pm 2.04 \mathrm{c}$ & $0.50 \pm 0.50 \mathrm{~b}$ & 40 & 40 & 10 \\
\hline 9 March & $9.10 \pm 2.16 b$ & $14.20 \pm 6.34 b$ & $8.00 \pm 5.17 \mathrm{a}$ & 90 & 60 & 30 \\
\hline 20 April & $21.30 \pm 2.78 a$ & $50.20 \pm 9.12 a$ & $9.10 \pm 5.35 a$ & 100 & 100 & 40 \\
\hline
\end{tabular}

${ }^{a}$ means with same letter in the same column are not statistically significant according to Tukey's HSD test (P < 0.005$)$.

\section{Longevity}

Female longevity was nearly 45 days in April but was significantly longer at 55 days in November $\left(F_{(6,54)}=4.677, P<0.0001\right.$; Table 5). Only one female survived for nearly 100 days in the November experiment. Some females from the November experiment lived for 2 months or slightly longer. Mean longevity of females of December, January and February were less than 30 days. Female life spans in March and April lasted slightly over 30 days (March $34.50 \pm 7.38$ days; April $44.74 \pm 4.21$ days). Mean longevity of the males in all experimental months were shorter than those found for females (Table 5). Males assessed in the October and November experiments survived for $30.62 \pm 8.82$ and $39.44 \pm 6.16$ days, respectively. Mean longevity of males in December and February were similar, and these males lived for 21 days. Longevity of males approached to nearly 30 days in March and April. 
Table 5. Longevity of Orius niger adults under outdoor conditions

\begin{tabular}{|c|c|c|c|c|c|c|}
\hline \multirow{3}{*}{ Experiment date } & \multicolumn{6}{|c|}{${ }^{\mathrm{a} L o n g e v i t y \text { (day) }}$} \\
\hline & \multicolumn{4}{|c|}{ Female } & \multicolumn{2}{|l|}{ Male } \\
\hline & Mean $\pm S E M$ & Max. & Min. & Mean \pm SEM & Max. & Min. \\
\hline 13 October & $39.77 \pm 5.19 \mathrm{~b}$ & 56 & 18 & $30.62 \pm 8.82 a$ & 46 & 13 \\
\hline 3 November & $55.00 \pm 0.10 \mathrm{a}$ & 98 & 16 & $39.44 \pm 6.16$ a & 67 & 9 \\
\hline 3 December & $28.50 \pm 4.44 \mathrm{c}$ & 56 & 14 & $21.80 \pm 3.65 a$ & 38 & 10 \\
\hline 5 January & $25.20 \pm 6.67 \mathrm{c}$ & 61 & 6 & $21.00 \pm 3.55 a$ & 41 & 6 \\
\hline 2 February & $20.25 \pm 4.62 \mathrm{c}$ & 39 & 3 & $21.12 \pm 5.79 \mathrm{a}$ & 51 & 4 \\
\hline 9 March & $34.50 \pm 7.38 \mathrm{~b}$ & 57 & 6 & $27.00 \pm 7.98 \mathrm{a}$ & 57 & 16 \\
\hline 20 April & $44.74 \pm 4.21 b$ & 63 & 30 & $29.71 \pm 9.52 \mathrm{a}$ & 50 & 4 \\
\hline
\end{tabular}

a means with same letter in the same column are not statistically significant according to Tukey's HSD test $(P<0.005)$.

\section{Discussion}

Winter in Southeastern Mediterranean region of Turkey is mild and rainy. All eggs laid by the females easily hatched during the outdoor experiments. Low rate of nymphs (nearly $20 \%$ ) survival was recorded in the winter (December-February). Durations of nymph development were nearly 20 days in autumn (October) and spring time but increased up to 30 days or slightly over 30 days in the winter. Mean temperature in October ranged from 19 to $22^{\circ} \mathrm{C}$, and 13 to $18^{\circ} \mathrm{C}$ in April but varied between 5 to $13^{\circ} \mathrm{C}$ in the winter (Figure 1). Duration of total nymph development of $O$. niger, when temperature increased to over $20^{\circ} \mathrm{C}$ under the controlled conditions, were less than 20 days. For example, Tommasini \& Nicoli (1996) reported that total duration of nymph development of $O$. niger provided with eggs of $E$. kuehniella and $F$. occidentalis as food were 12.9 and 11 days, respectively, at $26^{\circ} \mathrm{C}$ and $80 \pm 5 \% \mathrm{RH}$. Duration of total nymphal stage ranged from 16 to 18.8 days when nymphs of $O$. niger were exposed to $26^{\circ} \mathrm{C}$ and to various day lengths $(9-16 \mathrm{~h}$ ) (Bahşi \& Tunç, 2008). However, duration of nymphal instars of $O$. niger provided with nymphs of Bemisia tabaci and Tetranychus cinnabarinus was 21.5 and 21.8 days, respectively, under the laboratory conditions with $25 \pm 1^{\circ} \mathrm{C}$ and $65 \pm 10 \% \mathrm{RH}$ (Efe \& Çakmak, 2013).

Nymphal mortality was particularly higher in the winter and only $28 \%$ nymphs of a total 189 nymphs matured to adults. Similarly, Chyzik et al. (1995) found that survival rate of nymphs of Orius albidipennis (Reuter, 1884) in the winter in Israel was less than $20 \%$. Females of $O$. niger were found throughout autumn to spring in faba bean (Vicia faba L.) fields in the Adana Region, but no Orius nymph were detected on faba bean, other arable crops and wild plants until the first week of March (Atakan, 2010). This indicates that mortality rates of the early nymphs were high. Our findings are in accord with results of O. albidipennis in Irak (El-Serwiy et al., 1985) and O. laevigatus in Egypt (Tawfik \& Ata, 1973). Orius adults survived in the winter in some regions of Israel, but no nymphs were detected until the end of March on mango blossoms (Ben-Dov et al., 1992).

High numbers of eggs were laid in the experiments conducted in October and April. Females oviposited fewer eggs through the winter months. The rate of non-reproductive females was $40 \%$ in January and February. In Israel, most adult females laid eggs in the outdoor experiments conducted in October and April, but some females did not lay eggs and died (Chyzik et al., 1995). In our study, females in the October experiment oviposited and laid fewer eggs for two months. Also, one female from the November experiment oviposited for another 2 months. We suggest that the reason why some females did not lay eggs in the winter may be due to their lack of tolerance to low temperatures, and they might have not mated. 
In current study, the day length did not induce diapause in O niger. Chyzik et al. (1995) found that both females and males of $O$. albidipennis at the low mean temperature (below $15^{\circ} \mathrm{C}$ ) are active and feed on moth eggs but females do not lay eggs. Bahşi \& Tunç (2008) concluded that $9-13 \mathrm{~h}$ day length do not induce diapause and did not affect the development of $O$. niger. They suggested that $O$. niger could survive and reproduce under the winter conditions in heated greenhouses. According to data obtained in current study, $O$. niger from Turkey might be useful for controlling $F$. occidentalis under protected conditions in southern Europe and Mediterranean regions. However, It is known that some species of Orius show obligatory and facultative diapause, and diapause is induced by low temperature and short day length (Iglinsky \& Rainwater, 1950; Gillespie \& Quiring, 1993; Ramakers \& van den Meiracker, 1991).

In the current study, life spans of females in autumn and winter were less than 30 days and thus they did not survive till spring. Oviposition time of females in winter was less than 20 days. In Israel, mean longevity of $\mathrm{O}$. albidipennis from November and December experiments were significantly longer (84.2 and 125.2 days, respectively) (Chyzik et al., 1995), and females started to oviposit again at the end March. Differences between the two studies may be related to different climatic conditions and different species of Orius. Orius niger does not build up efficient outdoor population in winter and early spring time in the region because of short-lived females and males, low reproductive rates of females and high mortality rates of nymphs. Thus, it will not be possible to control outdoor winter and spring populations of small insects, including $F$. occidentalis, in the region.

Orius niger has effectively controlled flower thrips population in cotton flowers in the region (Atakan \& Gencer, 2008) and this predatory bug is more common in the Mediterranean region. Based upon some results of current study, $O$. niger could be employed as a biological control agent in IPM studies on pest thrips. Populations of $F$. occidentalis increase dramatically in spring in greenhouses and outdoors when many crops are flowering, requiring applications of pesticides. However, the present results suggest that densities of $O$. niger, even in the early spring, are still not high. Orius niger oviposit again in mid-March, and nymph populations appear on faba bean plants in late March (Atakan, 2010). Nymphs will become adults in mid-April. The predatory effect of the April population will be seen in May.

Finally, mortality rates of $O$. niger nymphs were high in winter to early spring. Additionally, most of the experimental females coming from the autumn and winter months were not able to survive till spring to produce nymphs. Therefore, $O$. niger might not be unable to control pest insects in the early vegetative period under open field conditions. For this reason, further studies in Turkey should focus on efforts to augment winter to early spring populations of this predator emphasizing earlier control of $F$. occidentalis. Diapause does not occur in the $O$. niger under short day length. Orius niger should be evaluated for control of $F$. occidentalis in greenhouses in Turkey. However, the reproductive rate of $O$. niger under laboratory conditions is lower than that of $O$. laevigatus (Tommasini et al, 2004), which is commercially used to control pest thrips in greenhouses in Turkey. Further studies are needed on rearing conditions for $O$. niger under laboratory conditions to enhance its mass production for release against pest thrips (mainly F. occidentalis).

\section{Acknowledgments}

We would like to extend our thanks to Prof. Dr. M. Bora KAYDAN (Vocational School of İmamoğlu, University of Çukurova, Adana, Turkey) and Mr. Tange Denis ACHIRI (MPhiL) (Department of Plant Protection, Faculty of Agriculture, University of Çukurova, Adana, Turkey) for reviewing of the manuscript. This study was supported by the Unit of Scientific Research Projects (Project no: FBA-2014-2488), Çukurova University, Adana, Turkey. 


\section{References}

Atakan, E., 2006. Associations between Frankliniella spp. and Orius niger populations in cotton. Phytoparasitica, 34: 221-234.

Atakan, E., 2007a. Thrips (Thysanoptera) species occurring on winter vegetables crops in Çukurova region of Turkey. Book of Abstracts of Second Symposium on Palaeartic Thysanoptera, Acta Phytopathologica Entomologica Hungarica, 43: 227-234.

Atakan, E., 2007b. Thrips (Thysanoptera) species occurring on fruit orchards in Çukurova region of Turkey. Book of Abstracts of Second Symposium on Palaeartic Thysanoptera, Acta Phytopathologica Entomologica Hungarica, 43: 235-242.

Atakan, E., 2010. Influence of weedy field margins on abundance patterns of the predatory bugs Orius spp. and their prey, the western flower thrips (Frankliniella occidentalis), on faba bean. Phytoparasitica, 38: 313-325.

Atakan, E. \& O. Gencer, 2008. Influence of planting date and the relationship between populations of Frankliniella flower thrips and predatory bug Orius niger in cotton. Journal of Pest Science, 81: 123-133.

Atakan, E. \& I. Tunç, 2010. Seasonal abundance of hemipteran predators in relation to western flower thrips Frankliniella occidentalis (Thysanoptera: Thripidae) on weeds in the eastern Mediterranean region of Turkey. Biocontrol Science and Technology, 20 (8): 821-839.

Bahşi, Ş. Ü. \& I. Tunç, 2008. Development, survival and reproduction of Orius niger (Hemiptera: Anthocoridae) under different period and temperature regimes. Biocontrol Science and Technology, 18 (8): 767-778.

Ben-Dov, Y., M. Wyski, E. Tomer, G. Ofek, \& Z. Avin, 1992. Observations on the phenology and control of the western flower thrips, Frankliniella occidentalis Pergande, of mango inflorescences in Israel. Alon Hanotea, 46 (8): 497-502.

Brødsgaard, H. F. 1994. Insecticide resistance in European and African strains of western flower thrips (Thysanoptera: Thripidae) tested in a new residue-on-glass test. Journal of Economic Entomology, 87: 11411146.

Chyzik, R., M. Klein, \& Y. Ben-Dov, 1995. Overwintering biology of the predatory bug Orius albidipennis (Hemiptera: Anthocoridae) in Israel. Biocontrol Science and Technology, 5 (3): 287-269.

Dağlı, F. \& I. Tunç, 2007. Insecticide resistance in Frankliniella occidentalis (Pergande) (Thysanoptera: Thripidae) collected from horticulture and cotton in Turkey. Australian Entomology, 46 (4): 320-324.

Efe, D. \& I. Çakmak, 2013. Life table parametres and predation of Orius niger Wolff (Hemiptera: Anthocoridae) feding on two different preys. Türkiye Entomoloji Dergisi, 37 (2): 161-167.

El-Serwiy, S. A., I. A. Razoki \& A. S. Ragap, 1985. Population density of Thrips tabaci (Lind.) and the predators Orius albidipennis (Reut.) and Aeolothrips fasciatus (L.) on onion. Journal of Agriculture and Water Resources Research, 4: 57-67.

Fathi, S. A. A., 2009. The abundance of Orius niger (Wolf.) and O. minutus (L.) in potato fields and their life table parameters when fed on two prey species. Journal of Pest Science, 82 (3): 267-272.

Ghavami, M. D \& A. F. Özgür, 1992. "Population development of pest and their interactions with predatory insects in cotton field, 227-238". Proceedings of the Second Turkish National Congress of Entomology (28-31 January, 1992, Adana, Turkey) (in Turkish with English abstract), 747 pp.

Gillespie, D. R. \& D. M. J. Quring, 1993. Extending seasonal limits on biological control. IOBC/WPRS Bulletin XVI, 43-45.

Iglinsky, W. J. \& C. F. Rainwater, 1950. Orius insidiosus, an enemy of spider mite on cotton. Journal of Economic Entomology, 43: 567-568.

Immaraju, J. A., T. D. Paine, J. A. Bethke, K. L. Robb \& J. P. Hewman, 1992. Western flower thrips (Thysanoptera: Thripidae) resistance to insecticides in coastal California greenhouses. Journal of Economic Entomology, 85: 9-14.

Jacopson, R., 1993. Control of Frankliniella occidentalis with Orius majusculus: experinces during the first full season of commercial use in UK. IOBC/WPRS Bulletin, 16, 81-84.

Kirk, W. D. J. \& L. I. Terry, 2003. The spread of the western flower thrips, Frankliniella occidentalis (Pergande). Agriculture and Forestry Entomology, 5 (4): 301-310. 
Önder, F., 1982. Contribution to the study of Turkish Anthocoridae (Heteroptera). Ege Üniversitesi, Ziraat Fakültesi Ofset Basımevi Bornova, İzmir, Turkey, (in Turkish, with English summary), $159 \mathrm{pp}$.

Ramakers, P. M. Y. \& R. A. F. van den Meiracker, 1991. Biological control of the western flower thrips with predatory mites and pirate bugs: Can do better than one? Annual Report 1991. Research Institute for Plant Protection, The Netherlands, 1-21.

Riudavets, J., 1995. "Predators of Frankliniella occidentalis (Perg.) and Thrips tabaci Lind.: A Review, 49-87". In: Biological control of Thrips pests, (Eds: A. J. M. Loomans, J. C. Van Lenteren, M. G. Tommasini, S. Maini \& J. Riudavets) Wageningen Agricultural University Papers, 95.I, Wageningen, 201 pp.

Schreuder, R. G. \& P. M. J. Ramakers, 1989. Onverwacthte hulp bij geintegreerde bestrijding. Groenten En Fruit, 45: 28-29.

SPSS, 2006. SPSS Base 15.0 User's Guide, Chicago: Prentice Hall.

Tavella, L., A. Arzone \& A. Alma, 1991. Researches on Orius laevigatus (Fieb.), a predator of Frankliniella occidentalis (Perg.) in greenhouses. A preliminary note. IOBC/WPRS Bulletin, 14: 65-72.

Tawfik, M. F. S. \& A. M. Ata, 1973. The life history of Orius laevigatus (Fieber) (Hemiptera: Anthocoridae). Bulletin Societe Entomologigue d' Egypte, 57: 117-126.

Tommasini, M. G. \& G. Nicoli, 1996. Evaluation of Orius spp. as biological control agents of thrips pests. Further experiments on the existence of diapause in Orius laevigatus. IOBC WPRS Bulletin, 19 (1): 183-186.

Tommasini, M. G. \& J. C. van Lenteren, 2003. Occurrence of diapause in Orius laevigatus. Bulletin of Insectology, 56 (2): $225-251$.

Tommasini, M. G., J. C. van Lenteren \& G. Burgio, 2004. Biological traits and predation capacity of four Orius species on two prey species. Bulletin of Insectology, 57 (2): 79-93.

Trottin-Caudal, Y., D. Grasselly, M. Trapateau, H. Dobelin \& P. Millot, 1991. Lutte biologique contre Frankliniella occidentalis avec Orius majusculus sur concombre. IOBC/WPRS Bulletin, 14 (5): 50-56.

Tunç, I. \& H. Göçmen, 1994. New greenhouse pests, Polyphagotarsonemus latus and Frankliniella occidentalis in Turkey. FAO Plant Protection Bulletin, 42: 218-220.

Van de Veire, M. \& D. Degheele, 1992. Biological control of the western flower thrips, Frankliniella occidentalis (Pergande) (Thysanoptera: Thripidae) in glasshouse sweet peppers with Orius spp. (Hemiptera: Anthocoridae). A comparative study between O. niger (Wolff) and O. insidiosus (Say). Biocontrol Scieince and Technology, 2 (4): 281-283.

Villevieille, M. \& P. Millot, 1991. Lutte biologique contre Frankliniella occidentalis avec Orius laevigatus sur fraisier. IOBC/WPRS Bulletin, 14: 57-64.

Whitcomb, W. H. \& K. Bell, 1964. Predaceous insects, spiders and mites of Arkansas cotton fields. Arkansas Experiment Station Bulletin, 690, 1-83. 